\section{A Chain Multiple Mediation Model Linking Strategic, Management, and Technological Innovations to Firm Competitiveness}

\author{
Chen Han' \\ Shanxing Gao ${ }^{1}$ \\ ${ }^{1}$ Xi'an Jiaotong University, School of Management, Xi'an, P.R. China
}

\section{Abstract}

Purpose - This study attempts to build an integrated framework to discuss the influence of three types of innovations, i.e. strategic, management, and technological innovations, on firm competitiveness.

Design/methodology/approach - Paired survey responses are collected from 303 firms located in China. A confirmatory factor analysis is implemented with SPSS AMOS software to check the reliability and validity of all measures through structural equation modeling. Four hypotheses are empirically examined with SPSS PROCESS Macro in combination with a bias-corrected bootstrapping technique to test the chain multiple mediation model linking strategic, management, and technological innovations to firm competitiveness.

Findings - Although strategic, management, and technological innovations are carried out at different organizational levels, they formulate a holistic framework to jointly improve firm competitiveness. Strategic innovation strengthens firm competitiveness through three parallel routes, i.e. via management innovation, via technological innovation, and via the serial mediating mechanism of management and technological innovations. Also, the mediation effect of management innovation is significantly stronger than that of technological innovation.

Originality/value - This study integrates strategic, management, and technological innovations into the process of improving firm competitiveness to account for their joint influences, challenging the conventional paradigm where different types of innovations are investigated separately. Cross-domain knowledge flow, exchange, and combination are realized within the broad innovation construct.

Keywords - strategic innovation, management innovation, technological innovation, firm competitiveness, chain multiple mediation
Received on

06/26/2018

Approved on

05/17/2019

Responsible editor:

Dr. João Maurício Gama

Boaventura

Evaluation process:

Double Blind Review

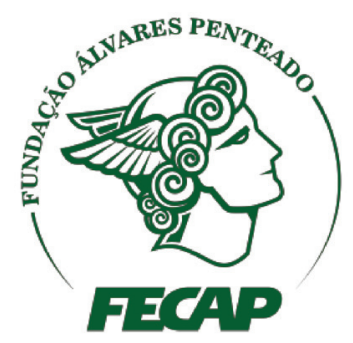

Review of Business Management

DOI: $10.7819 /$ rbgn.v21i5.4030 


\section{Introduction}

Innovation is a hot topic for both academics and practitioners. Scholars continue to promote innovation research from various perspectives. Crossan and Apaydin's (2010) systematic review of the innovation literature analyzes academic articles published between 1981 and 2008 to synthesize various perspectives into a multi-dimensional framework of the field of innovation. They note that one crucial aspect of the innovation research is concerned with the classification of innovation into different types, among which the differentiation between technological and non-technological innovation is fundamental.

Extant literature drawing on the technological vs non-technological typology acknowledges that non-technological innovation is increasingly becoming a prominent yet previously overlooked factor which stimulates firm performance through facilitating product and process innovation (Armbruster, Bikfalvi, Kinkel, \& Lay, 2008) and enhancing productivity and flexibility (Goldman, Nagel, \& Preiss, 1995; Womack, Jones, \& Roos, 2007).

Although the value of distinguishing between the concept of non-technological innovation and the overwhelmingly more studied construct of technological innovation is increasingly recognized, the literature on nontechnological innovation is highly fragmented, loosely connected, conceptually ambiguous, and lacks a comprehensive understanding (Černe, Kaše, \& Škerlavaj, 2016; Damanpour \& Aravind, 2012).

First, a considerable amount of academic attention is paid to management/administrative innovation (Daft, 1978; Damanpour \& Evan, 1984; Gopalakrishnan \& Damanpour, 1997; Tether \& Tajar, 2008), whereas other important non-technological innovation types are largely under-researched (Černe et al., 2016). Strategic innovation (Afuah, 2009; Kodama, 2004; Lee, Olson, \& Trimi, 2010; Schlegelmilch, Diamantopoulos, \& Kreuz, 2003), business model innovation (Foss \& Saebi, 2017, 2018; Teece, 2010; Zott \& Amit, 2008), marketing innovation (Chen, 2006; Crick \& Crick, 2016; Nieves \& Diaz-Meneses, 2016; Simmonds \& Smith, 1968), and green or eco-innovation (Engert, Rauter, \& Baumgartner, 2016; Ghisetti, Marzucchi, \& Montresor, 2015; Klewitz \& Hansen, 2014; Schiederig, Tietze, \& Herstatt, 2012) are representative types of non-technological innovations deserving further academic attention.

Second, most of the current literature on non-technological innovation has been produced in market economies such as Europe and the US (Černe, Jaklič, \& Škerlavaj, 2015; Walker, Chen, \& Aravind, 2015), with only a few exceptions from emerging economies, especially China (Guo, Tang, Su, \& Katz, 2017; Luk et al., 2008; Yiu \& Lau, 2008). Although the research on technological and non-technological innovations per se is not context-specific, scholars do conduct empirical research in different countries using various data sources. Walker, Chen, \& Aravind's (2015) meta-analysis concludes that both management and technological innovations contribute to firm performance, but context/ country is proved to be an important moderator which affects the innovation-performance link. We acknowledge that our study is not intended to provide a comprehensive understanding of the influence of non-technological innovation on firm performance in various countries or to account for the contextual differences caused by cultures and values. We merely aim to enrich the empirical evidence on non-technological innovation in China.

To address the abovementioned research gaps, this paper builds an integrated research model to analyze the impact of three types of innovations on firm performance: strategic innovation, management innovation, and technological innovation. In doing so, we bring in a fine-grained distinction of non-technological innovations, i.e., strategic and management innovations, and link them to technological innovation. Management innovation has been the dominant theme of nontechnological innovation. Our study incorporates 
strategic innovation into management innovation to formulate non-technological innovation as an umbrella concept. Specifically, we seek to explore the following research question: How do strategic innovation, management innovation, and technological innovation collectively impact firm competitiveness?

Empirical tests using paired survey data collected from 303 firms in China confirm our hypotheses. Strategic innovation strengthens firm competitiveness via (1) the mediation effect of management innovation, (2) the mediating role of technological innovation, and (3) the serial meditation link with management innovation and technological innovation as chain mediators. Furthermore, management and technological innovation show heterogeneous impacts, with management innovation being a more prominent mediator.

We hope to contribute to innovation literature in two ways. First, a fine-grained typology of non-technological innovation, composed of strategic innovation and management innovation, is introduced to the non-technological innovation literature. An integrated research framework is built to analyze the interplay between three types of firm innovations and firm competitiveness. In this way, we enrich current literature on the relationship between technological and nontechnological innovation, especially multiple types of non-technological innovations. Second, we enrich the empirical evidence on nontechnological innovation using Chinese data. China is an overlooked empirical setting in the field of non-technological innovation. We add Chinese evidence to the extant European and US evidence to facilitate a deeper understating of non-technological innovation.

\section{Theoretical Framework and Hypotheses}

\section{I Innovation and firm competitiveness: a tale of three innovation types}

Since Schumpeter's innovation theory defines innovation as establishing a new production function, i.e., the recombination of production factors, and distinguishes five types of innovations (Schumpeter, 1934), scholars have classified innovation according to various criteria (Černe et al., 2016; Crossan \& Apaydin, 2010; Han, Kim, \& Srivastava, 1998). According to the dual-core theory of innovation, organizational innovation includes technology core and management core (Daft, 1978). Changes and innovations in the organization's technological system require corresponding changes and innovations in the administrative/management system to serve as a necessary precondition for the full implementation and exploitation of technological innovations (Azar \& Ciabuschi, 2017; Damanpour, Szabat, \& Evan, 1989). From a technical core perspective, technological innovation is the organizational output of new technologies, products, and services. By contrast, management/administrative innovations are the organizational changes that take place in the administrative system from a management core perspective. The technical core and management core correspond to technological innovation and management innovation respectively, reflecting the general differentiation between the technical system and the social system of an organization (Crossan \& Apaydin, 2010).

However, a broader perspective of innovation considers technological and nontechnological innovations (Černe et al., 2016). Non-technological innovations are innovations including non-technical elements, composed of management innovation (also known as managerial innovation or administrative innovation), strategic innovation, business model innovation, marketing innovation, and green or eco-innovation, among others.

Innovation constitutes one crucial source of substantial competitive advantage, regardless of its various types (Schumpeter, 1934). Technological product and process innovations drive firm performance through the advancement of novel technologies and the introduction of new products and services (Daft, 1978; Damanpour 
\& Evan, 1984). Non-technological innovations show positive effects on firm growth and business performance by promoting the productivity, flexibility, and quality of the corporate system and pushing technological innovation (Azar \& Ciabuschi, 2017; Camisón \& Villar-López, 2014; Daft, 1978; Damanpour \& Evan, 1984; Hollen, Van Den Bosch, \& Volberda, 2013; Lam, 2005).

Instead of investigating technological and management innovation, which draws on the general distinction between technical and administrative systems of an organization (Daft, 1978; Damanpour \& Evan, 1984), this paper adopts Černe et al.'s (2016) perspective, which considers all types of innovations that include a non-technical component. So, innovations are composed of technological and non-technological innovations, and strategic innovation and management innovation are essential nontechnological innovation types. This gives rise to the three types of innovations which are of particular interest in this paper. We next briefly describe each of them and their impacts on firm competitiveness.

Strategic innovation refers to developing novel and nontrivial changes in business models and utilizing extraordinary competitive strategies to break the current market rules (Lee et al., 2010; Schlegelmilch et al., 2003). Management innovation involves the invention and adoption of new management processes, practices, and structures targeted at improving organizational performance and attaining organizational goals (Birkinshaw, Hamel, \& Mol, 2008). Technological innovation is the process of conceiving, researching, developing, and introducing new products and services to the market. It includes the whole process and outcome of product and service development (Crossan \& Apaydin, 2010).

The influence of strategic innovation on firm competitive advantage is drawing increasing academic attention, and its mechanism can be explained in the following four aspects. First, corporate-level strategic innovation creates a unique strategic mindset and framework to assist the value transformation process of firm resources and capabilities through redefining the customer and market base (Geroski, 1998; Hamel, 1996, 1998c; Markides, 1997, 1998; Schlegelmilch et al., 2003). Innovation at the corporate strategy level is especially crucial when the resource scarcity tension is present because strategic innovation breaks the conventional paradigm of matching resources with opportunities (Kim \& Mauborgne, 1997). By designing and implementing a unique strategy or business model, firms creatively exploit, integrate, and reconfigure their resources, and develop potential business and entrepreneurial opportunities, thus converting internal resources into external values and performance.

Second, strategic innovation is an aggressive way of reshaping and influencing the market and industry environment. Firms carrying out strategic innovation not only better fit into their competitive situations, but also restlessly redefine and reform their external environments, thus improving their competitiveness (Teece, 2010).

Third, strategic innovations strongly emphasize customers at the core of corporate strategies. They utilize non-customers' unique insights into emerging trends and opportunities and cross the boundary of existing customer markets (Kim \& Mauborgne, 1999b; Schlegelmilch et al., 2003). This enables firms to identify and take advantage of both real and potential opportunities ahead of competitors, guarantee the first mover advantage, and occupy the customer market in advance. This predominance creates an implicit barrier to entry (Priem, Butler, \& $\mathrm{Li}, 2013)$. Competitors and followers consume more resources and expend more effort when developing homogenous products and stepping into the same market. Rational competitors and imitators switch to other target markets where they have relatively more advantage.

Fourth, strategic innovations force firms to remain adaptive by innovating in competitive strategies. Due to the uniqueness of strategic 
innovation and the tremendous transformations and changes involved, firms are doomed to experience extreme pain in the early stages of strategic innovation. However, as time passes, the success of strategic innovation becomes more prominent, and the firms are increasingly rejuvenated. On the contrary, if a firm maintains a static strategy and does not implement strategic innovations, it will inevitably limit its creativity and long-term development, miss future opportunities, and eventually decline. In summary, strategic innovation helps to enhance firm competitiveness.

Management innovation optimizes organizational processes and improves operational efficiency (Birkinshaw et al., 2008; Camisón \& Villar-López, 2014). The intangible nature of management innovation makes it extremely difficult to imitate (Černe et al., 2015). By transforming regulatory processes, methods, and processes, it is possible to significantly elevate the entire management process, improve operational efficiency and effectiveness, and enable market opportunities to be grasped. Therefore, management innovation substantially enhances firm competitiveness.

Technological innovation significantly enhances firm competitiveness. First, the resourcebased view emphasizes the core role of valuable, rare, imperfectly imitable, and non-substitutable resources and capabilities in promoting firm performance and firm competitive advantage. In the $R \& D$ process of technologically innovative products and services, firms build up their heterogeneous, tacit, and casually ambiguous knowledge, which prevents competitors from imitating and reverse engineering and thereby ensures the firms stay ahead of their competitors.

Second, technological innovation works as an implicit appropriability regime. In addition to the appropriability regime such as intellectual property rights and patents, the protection of a firm's core technologies and capabilities is embedded in the entire R\&D process of technologically innovative products and services. The innovative outputs are exclusively appropriated by the focal firm, conferring the firm a significantly stable competitive position.

Third, technological innovation is the pursuit of knowledge and technology trends. It can create new products that customers have never heard of before, meet emerging customer needs, capture market share, and help maintain long-term competitiveness.

From the above analysis, we can conclude that three types of innovation, i.e., strategic, management, and technological innovations, are beneficial to firm competitiveness. However, these three types of innovation also have significant differences. First, technological innovation is external-oriented, which is related mainly to the entire process of conceiving, researching, developing, and introducing new products and services to the market (Hervas-Oliver \& Sempere-Ripoll, 2015). Strategic innovation and management innovation are more internaloriented, concerning changes in business models and competitive strategies and the enhancement of operational efficiency. Second, strategic innovation is concerned with not only strategic planning but also the implementation of significant changes at all organizational levels (Černe et al., 2016). In other words, strategic innovation is a comprehensive mechanism which embraces and impacts all the other types of innovation, no matter whether they are technological or non-technological.

To conclude, strategic innovation is an over-arching type of innovation which is more likely to be an antecedent of management and technological innovations. Moreover, technological innovation focuses on satisfying market objectives, so it will more probably be an outcome of strategic and management innovations. In light of this, we develop our theoretical model as Figure 1. 


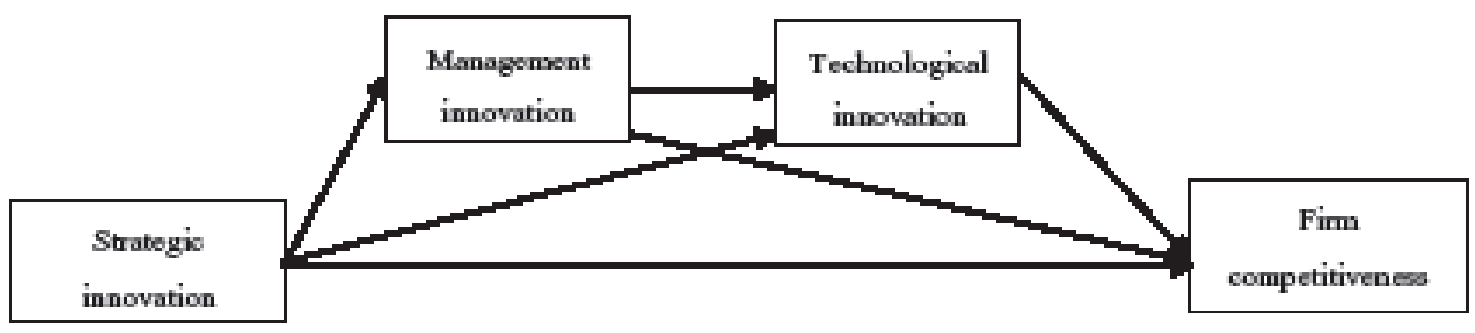

Figure 1. Theoretical model

Notes. H1: strategic innovation $\rightarrow$ management innovation $\rightarrow$ firm competitiveness; H2: strategic innovation $\rightarrow$ technological innovation $\rightarrow$ firm competitiveness; H3: relative mediation effect: management innovation>technological innovation; H4: strategic innovation $\rightarrow$ management innovation $\rightarrow$ technological innovation $\rightarrow$ firm competitiveness.

\subsection{Strategic innovation, management innovation, and firm competitiveness}

Strategic innovation is a relatively new concept, appearing in the late 1990s. The most traditional understanding of strategic innovation is the application of innovation to corporate strategies (Krinsky \& Jenkins, 1997). Conventionally, innovation and strategy are regarded as two separated fields (Krinsky \& Jenkins, 1997). Innovation is a product-level construct mainly concerned with new product and service development. On the other hand, strategy resides at the corporate level, centering on strategy planning and implementation. Strategic innovation emerges through the intersection and combination of strategy and innovation. It involves developing novel and unique business models and utilizing extraordinary competitive strategies to break the current market rules, alter the nature of market competition, and reintegrate existing customer markets to achieve significant growth in customer value and corporate profits (Lee et al., 2010; Schlegelmilch et al., 2003). Similar terms include nonlinear innovation (Hamel, 1998a), strategy innovation (Hamel, 1996, 1998b, 1998c, 1999), value innovation and blue ocean strategy (Kim \& Mauborgne, 1997, 1999a, 1999b), discontinuous innovation (Lynn, Morone, \& Paulson, 1996), and competitive innovation (Hamel \& Prahalad, 1989, 1993, 1994a, 1994b).
The rise of management innovation stems from Daft's (1978) dual-core theory of organizational innovation. The technical core is related to the conversion of raw materials into the output of products and services; the management core refers to the organizational structure and administrative system. Technological innovation and management innovation correspond to the core of technology and the core of management, which together constitute the competitive advantage of the enterprise. Although technological innovation has brought about a significant increase in the productivity of enterprises, increasing competition has led to the imitation and reverse engineering behavior of competitors (Doha, Pagell, Swink, \& Johnston, 2017; Minagawa, Trott, \& Hoecht, 2007). Innovation based solely on technology is not enough to maintain the competitive advantage of enterprises. Management innovation, the "soft" power of the leading enterprise, introduces fundamental changes in organizational structure, processes, and procedures (Birkinshaw et al., 2008; Hargrave \& Van De Ven, 2006). It has become increasingly prominent in the survival and development of enterprises. Subsequently, the American scholar Stata (1989) proposed that US industry's primary bottleneck of progress is management innovation. Since then, an upsurge of management enthusiasm has been witnessed. Despite its different definitions and perspectives, most scholars recognize 
Birkinshaw, Hamel, and Mol's (2008) definition of management innovation, i.e., innovations in firms' administrative systems aimed at optimizing the organizational structure and improving the operational efficiency of the organization (Birkinshaw et al., 2008).

We expect a positive impact of strategic innovation on management innovation due to two reasons. First, strategic innovation represents fundamental changes and innovations in competitive strategies in the corporate model. It reflects the strategic vision of the top management team (Gebauer, Worch, \& Truffer, 2012; Lee et al., 2010). On the other hand, management innovation refers to changes in the organizational and operational structures and rules made at the management practice level and initiated by middle managers (Damanpour \& Aravind, 2012), which reflects the needs of the middle managers of the company to change the specific structure and administrative rules of the organization. The strategic planning of novel competitive strategies and business models can be understood as a well-designed process composed of identifying organizational goals and planning a competitive strategy, which is followed by the implementation of the new business model and competitive strategy throughout the organization to reach the predetermined goals. Top managers are the initiators of strategic innovation (Carpenter, Geletkanycz, \& Sanders, 2004). Once the concept of breaking and redefining the existing corporate strategy and business model is determined, it will be communicated and implemented top-down (Hart, 1992; Rapert, Velliquette, \& Garretson, 2002). Therefore, middle managers will inevitably and naturally improve the organizational structure according to the requirements of strategic innovation (Raes, Heijltjes, Glunk, \& Roe, 2011) and adjust the internal organizational structure and management rules to fully unlock the potential of novel strategies and business models (Neugebauer, Figge, \& Hahn, 2016).

Second, strategic innovation defines the firm's domain of strategic activity and mode of competition (Lee et al., 2010). Management innovation is the transformation of the organization's overall structure, rules and regulations, and management practices (Damanpour \& Aravind, 2012). Management innovation is far more complex, extensive, and challenging to achieve than technological product and process innovations (Damanpour \& Evan, 1984). Therefore, effective strategic guidance at the top managers level is crucial. Moreover, changes in strategies precede changes in structures, processes, and techniques, rather than the other way around (Chandler, 1962; Wischnevsky \& Damanpour, 2008).

Because strategic innovation leads to management innovation, which in turn contributes to firm competitiveness, we posit that strategic innovation enhances firm competitiveness through the mediation effect of management innovation. The temporal precedence of strategic changes ahead of structural and procedural changes and novelty (Wischnevsky \& Damanpour, 2008) facilitates the successful transmission and manifestation of the influence of strategic innovation on firm competitiveness through the adjustment in organizational structure, processes, and management techniques (Raes et al., 2011).

H1: Management innovation positively mediates the relationship between strategic innovation and firm competitiveness.

\subsection{Strategic innovation, technological innovation, and firm competitiveness}

Technological innovation is the process of conceiving, researching, developing, and introducing new products and services to the market. It includes the whole process and outcome of product and service development (Crossan \& Apaydin, 2010).

We think that strategic innovation has a positive impact on technological innovation. First, strategic innovation comes from dissatisfaction with the current market and industry competition status (Schlegelmilch et al., 2003). It focuses 
on the potential directions and approaches of competitors, rather than the status quo (Gebauer et al., 2012). Therefore, firms that carry out strategic innovation will question and extensively explore all aspects of industry competition and firm growth (Milutinović, Stošić, \& Mihić, 2015). They have first mover advantage and are faced with more strategic choices, so they are capable of discovering more potential opportunities. In these circumstances, the process of conceiving, researching, developing, and introducing new products and services (Crossan \& Apaydin, 2010) is more likely to be carred out, i.e., technological innovation is easier and more effective.

Second, strategic innovation integrates and re-defines the existing customer market and actively changes the current competition model (Hamel, 1996; Kim \& Mauborgne, 1999a, $1999 b)$. It is by no means passively adapting to external demands and industry trends. Firms with strategic innovation will never stop expanding the scope of competition. Any unrecognized potential market becomes the target of strategic innovators (Berghman, Matthyssens, \& Vandenbempt, 2012), and therefore they are more inclined to adopt unprecedented technological innovations to build a sustainable competitive advantage.

Third, strategic innovation enables significant leaps in customer value and focuses more on the core role of customer skills and customer involvement in firm growth and development (Krinsky \& Jenkins, 1997; Markides, 1999; Schlegelmilch et al., 2003). By including and considering the potential customer demands, firms develop more new products and services ahead of competitors' awareness.

Since strategic innovation contributes to technological innovation, which in turn enhances firm competitiveness, we go further to argue that strategic innovation enhances firm competitiveness through the mediation effect of technological innovation.

Technological innovation fully unlocks the potential impact of strategic innovation embedded in the continuous and extensive questioning, redefining, and exploring of current industry competition rules, models, and unique competitiveness strategies with tremendous value (Gebauer et al., 2012). It is through technological innovation activities that firms' inclination to discover more potential technological and market opportunities is increased. Also, a sustained focus on the core role of customer skills and customer involvement facilitates new product and service development with first mover advantage, thus significantly enhancing firm competitiveness.

H2: Technological innovation positively mediates the relationship between strategic innovation and firm competitiveness.

\subsection{The relative magnitude of the mediating effect of management innovation and technological innovation}

Since both management innovation and technological innovation play an intermediary role between strategic innovation and firm competitiveness, are there any differences in terms of the relative magnitude of the two mediation paths?

The theory of firm competitive advantage emphasizes a firm's ability to benefit from market competition and long-term growth relative to its competitors (Hitt, Ireland, \& Hoskisson, 2012). In the knowledge age, interfirm rivalries are intensified, and technologies are rapidly advancing. To maintain long-term competitiveness, firms need not only to conduct $\mathrm{R} \& \mathrm{D}$ independently to develop new products and technologies with independent intellectual property rights but also keep the operational efficiency of their internal administrative systems through optimizing resource allocation strategies. Therefore, technological innovation and management innovation both fundamentally enhance firm competitiveness. However, given their unique characteristics, their strengths of impacts on firm competitiveness differ. Management plays a much more significant role in enhancing firm competitiveness. 
First, technological innovation only includes the R\&D, production, and commercialization of new technologies and new products, which are implemented by technical departments and personnel. Management innovation, on the other hand, has a broader coverage, encompassing all aspects of business operations and management, such as $\mathrm{R} \& \mathrm{D}$, manufacturing, and human resource departments (Damanpour \& Aravind, 2012; Damanpour \& Evan, 1984; Damanpour, Sanchez-Henriquez, \& Chiu, 2018), and it is usually advanced by senior or top managers' decision making and top-down strategic implementation processes (Hart, 1992; Rapert et al., 2002). Therefore, compared to technological innovation, management innovation has a far-reaching and extensive influence on all aspects of long-term firm competitiveness. On the contrary, the scope of technological innovation is very focused, and it is usually implemented by professional technicians (Damanpour et al., 2018). Its influence is associated more with new products and processes, with a relatively weaker impact on the competitiveness of the entire enterprise.

Second, management innovation involves the whole operation process of an organization with the management knowledge embedded in the firm's administrative system, which is more complicated and difficult for competitors to observe and imitate (Černe et al., 2015; Volberda, Van Den Bosch, \& Heij, 2013). So, management innovation is more exclusive than technological innovation, and the management innovation process takes much longer (Volberda, Van Den Bosch, \& Mihalache, 2014). This gives management innovation adopters much more lead time to capture their competitive advantage.

Therefore, although technological innovation and management innovation both contribute to improving competitiveness, the impact of management innovation is stronger. Since management innovation can bring stronger competitive advantages to the firm in the longterm future than technological innovation, it occupies a more significant role in transforming strategic innovation into firm competitiveness. So, this study hypothesizes the following:

H3: The positive mediating effect of management innovation is more significant than that of technological innovation in the relationship between strategic innovation and firm competitiveness.

\subsection{Towards a chain multiple mediation mechanism}

Two mediating paths linking strategic innovation to firm competitiveness through management innovation and technological innovation have been established. However, management innovation and technological innovation are not causally unrelated.

Management innovation optimizes the entire process of technological innovation from idea generation to product development (Azar \& Ciabuschi, 2017; Le Bas, Mothe, \& Nguyen-Thi, 2015), it eliminates the systemic risk of technological innovation caused by organizational rigidity, and it promotes the R\&D of products and services (Birkinshaw et al., 2008; Damanpour \& Evan, 1984; Khosravi, Newton, \& Rezvani, 2019). Also, management innovation dramatically enhances a firm's sensitivity and responsiveness (Azar \& Ciabuschi, 2017) and creates an organizational atmosphere that favors new products and services (Damanpour \& Evan, 1984; Gunday, Ulusoy, Kilic, \& Alpkan, 2011). Therefore, management innovation promotes technological innovation.

Based on the above analysis, it is concluded that the relationships among strategic innovation, management innovation, and technological innovation are as follows when considering an integrated framework of their joint effects on firm competitiveness.

Strategic innovation is a firm's top-down strategic processes (Hart, 1992; Rapert et al., 2002), diffusing in the entire enterprise and representing the pursuit of a forward-looking 
competitive strategy by observing, analyzing, and reacting to the competitive environment ahead of competitors, and actively guiding and shaping the competitive condition (Neugebauer et al., 2016; Raes et al., 2011). Carried out at the corporate level (Carpenter et al., 2004), strategic innovation improves the pursuit of a new organizational structure and operational processes in the administrative component (Wischnevsky \& Damanpour, 2008), thus facilitating management innovation. The increased level of management innovation in turn shapes the organizational climate and shared vision (Hamel, 1998c), making them conducive to technological innovation; it reduces the systematic risks in the technological product development process (Birkinshaw et al., 2008); it improves the firm's R\&D initiative, responsiveness, and flexibility (Neugebauer et al., 2016); and it enhances the firm's willingness and confidence to engage in challenging and high-risk technological product and service innovation (Birkinshaw et al., 2008). The increased technological innovation enriches the firm's heterogeneous, tacit, and casually ambiguous knowledge, builds the capability to cater for emerging needs and capture potential market share, and works as an implicit appropriability regime which prevents competitors from imitating and reverse engineering. Ultimately, firm competitiveness is improved. Therefore, the following hypothesis is proposed:

H4: Strategic innovation positively affects management innovation, which in turn promotes technological innovation, which in turn enhances firm competitiveness.

\section{Methods}

\section{I Sample and data collection}

The hypotheses were empirically tested with 303 paired survey questionnaires collected from mainland China. We first extensively searched for measures from extant studies to generate some potential measures to choose from for each variable. Then we had discussions with several academic scholars and practitioners to select the measures that best fit the Chinese context. We used the chosen measures to generate the initial English version questionnaire. To guarantee language accuracy and equivalence, the English version questionnaire was translated into Chinese and then back-translated into English by two independent translators who are competent in both languages to increase cross-cultural equivalence (Douglas \& Craig, 2006). Then, a pilot study was conducted with 20 top managers from ten randomly selected firms located in Xi' an (two top managers for each firm). They read and provided feedback on the questionnaire regarding the content and format. The questionnaires were refined according to their comments, and the questionnaire was finalized.

The on-site interviews spanned from August 2010 to January 2011, which enabled us to judge whether the interviewees were competent and suitable and allowed the interviewees to ask for detailed explanations of the study. Because mainland China is composed of three regions according to the level of economic development (the east and coastal region, the middle region, and the west region), the stratified sampling method was employed to account for interregional differences. 31 provinces were divided into three categories according to their gross domestic product (GDP) rankings in $2009^{1}$, which was the latest GDP ranking available before the survey. 500 firms were randomly selected for each group, totally 1500 firms. All the target firms were initially contacted through telephone or email to ask for their willingness to participate in the survey. Then trained interviewers were sent to these firms to perform structured face-to-face interviews. All respondents were informed of the strict anonymity and confidentiality of the survey, guaranteed they would obtain a copy of our research findings, and given a small gift for their effort. In this way, this study succeeded in increasing the rate and quality of the responses and 
in decreasing social desirability bias (Fisher, 1993; Podsakoff, MacKenzie, Lee, \& Podsakoff, 2003). For each firm, two top or middle managers filled in the two identical questionnaires independently, taking roughly an hour on average. Eventually, our study obtained 303 paired questionnaires from 303 respondent firms (two paired responses for each firm). The overall response rate of $20.2 \%$ (303/1500) was acceptable for survey-based research (Kriauciunas, Parmigiani, \& RiveraSantos, 2011).

To check nonresponse bias, a one-way analysis of variance (ANOVA) regarding firm age and firm size was conducted for early and late respondents (Armstrong \& Overton, 1977). No statistical difference was found between the two groups, showing nonresponse bias is not a severe problem.

\subsection{Measures}

Except for control variables, 7-point Likert scales were utilized to measure the constructs, with 1 representing "strongly disagree" and 7 representing "strongly agree." All measures came from established studies, allowing for high reliability and validity.

\subsection{Independent variable}

The four items of strategic innovation came from Markides (1998) and were adjusted based on the characteristics of the Chinese context. They measure the extent of uniqueness and value in firm strategies and the efforts firms devoted to developing and maintaining their strategies.

\subsubsection{Mediating variables}

Management innovation was taken from Birkinshaw et al. (2008) and Vaccaro, Jansen, Van Den Bosch, and Volberda (2012), with four items to indicate the extent of novelty regarding new methods, procedures, and systems to achieve organizational objectives.

Technological innovation came from $\mathrm{Li}$ and Atuahene-Gima (2001). Three items were adopted to measure the firms' innovativeness in scientific research, technological inventions, new products, services, and processes development.

\subsubsection{Dependent variable}

Firm competitiveness was measured using four items from Wu, Wang, Chen, and Pan (2008). Respondents were asked to evaluate the firm's relative competitive advantage compared with its major competitors in terms of defeating competitors, providing high-quality products and services, recognizing changes in market rules, and responding to emerging opportunities.

\subsubsection{Control variables}

To minimize potential confounding effects, six organizational and industry level factors related to firm innovation and performance were controlled. Firm age was computed as the natural logarithm of the number of years from the firm's foundation to the year when the survey was conducted (2010). Firm size was the natural logarithm of the total number of employees. Firm ownership was a dummy variable, with stateowned firms marked as 1 and non-state-owned firms marked as 0 . Hi-tech firms were coded as 1 and non-hi-tech firms coded as 0. Industry competitive intensity was operationalized with a five-point Likert scale, with 1 representing no competition and 5 representing intense competition. Industry development stage included four stages (input stage, development stage, mature stage, and recession stage), marked 1 to 4 respectively.

\section{Analyses and Results}

\section{I Construct reliability and validity}

SPSS AMOS version 22.0.0 was used to perform structural equation modeling (SEM) with a confirmatory factor analysis (CFA) to evaluate our measures. Models with increasing complexity (i.e., the number of latent factors) were compared (Kline, 2010). We assessed four measurement models: (i) a one-factor model with 
all items loaded to a single latent construct; (ii) a two-factor model in which firm competitiveness formed the first latent factor and other items related to firm innovation constituted the second latent factor; (iii) a three-factor model in which firm competitiveness and technological innovation were two latent factors and other measures were loaded to the third factor reflecting non-technological innovation, including both strategic innovation and management innovation; (iv) a four-factor model linking each item to its corresponding latent construct. Table 1 details the model fit statistics of the four measurement models.
We performed a series of $\chi 2$ difference tests. The difference between Model ii and Model i was: delta $\chi 2=271.015$, delta $\mathrm{df}=1, \mathrm{p}<0.001$; the difference between Model iii and Model ii was: delta $\chi 2=211.99$, delta $\mathrm{df}=2, \mathrm{p}<0.001$; and the difference between Model iv and Model iii was: delta $\chi 2=261.825$, delta $\mathrm{df}=3, \mathrm{p}<0.001$. The significant pairwise $\chi 2$ difference tests suggested that each more differentiated model fitted the data significantly better than the less differentiated model, i.e., model fit: fmodel fit: four-factor model $>$ threefactormodel $>$ two-factor model $>$ onefactormodel.

Table 1

\section{Model fit indices for measurement models}

\begin{tabular}{|c|c|c|c|c|c|c|c|c|c|c|}
\hline Models & $\chi^{2}$ & df & $\mathbf{P}$ & $\chi 2 / \mathrm{df}$ & GFI & CFI & IFI & TLI & SRMR & RMSEA \\
\hline (i) One-factor model & 951.037 & 90 & $\mathrm{p}<0.001$ & 10.567 & 0.660 & 0.661 & 0.663 & 0.605 & 0.108 & 0.178 \\
\hline (ii) Two-factor model & 680.022 & 89 & $\mathrm{p}<0.001$ & 7.641 & 0.732 & 0.767 & 0.769 & 0.726 & 0.096 & 0.148 \\
\hline (iii) Three-factor model & 458.032 & 87 & $\mathrm{p}<0.001$ & 5.265 & 0.797 & 0.854 & 0.855 & 0.824 & 0.079 & 0.119 \\
\hline (iv) Four-factor model & 196.207 & 84 & $\mathrm{p}<0.001$ & 2.336 & 0.922 & 0.956 & 0.956 & 0.945 & 0.049 & 0.067 \\
\hline
\end{tabular}

The standardized factor loadings from CFA of the four-factor measurement model are listed in Table 2, together with average variance extracted (AVE), Cronbach $\alpha$, and composite reliability (CR) to evaluate the reliability and validity of all variables.

Cronbach $\alpha$ (Nunnally, 1978) and Composite Reliability (CR) (Bagozzi \& Yi, 1988) were computed to assess the reliability of all constructs. As shown in Table 2, all latent variables have a Cronbach $\alpha$ above or close to the threshold of 0.7 and CR values above the benchmark of 0.7 , indicating good reliability.

Since we established the four-factor model as a perfect fit for the data in the above CFA, we complemented it with AVEs. Because the standardized factor loadings obtained from the four-factor measurement model and AVEs exceed the threshold of 0.7 and 0.5 respectively, an excellent convergent validity was obtained (Fornell \& Larcker, 1981).
The discriminant validity test was conducted utilizing the procedure suggested by Fornell and Larcker (1981). In Table 3, the square roots of AVE for each variable are along the diagonal, and the Pearson correlation coefficients between all constructs are below the diagonal. For each variable, the square root of AVE is bigger than the Pearson correlation coefficients with all other variables, supporting good discriminant validity.

\subsection{Common method bias}

Two identical questionnaires were distributed to two key respondents in each firm. They were asked to reply independently and simultaneously. Exogenous and endogenous variables were chosen from the two samples respectively, reducing a substantial amount of common method bias. Also, two additional techniques were employed. First, Harman's onefactor test (Podsakoff \& Organ, 1986) generated 
no single dominant factor with most of the variances using exploratory factor analysis (EFA) with no rotation. Second, the fit of the model which loads all items to one factor was computed with CFA (Sabherwal \& Becerra-Fernandez, 2005). The terrible model fit $(\chi 2=951.037, \mathrm{df}=90$, $\mathrm{p}<0.001, \chi^{2 / \mathrm{df}}=10.567, \mathrm{GFI}=0.660, \mathrm{CFI}=$ $0.661, \mathrm{IFI}=0.663, \mathrm{TLI}=0.605, \mathrm{SRMR}=0.108$, RMSEA $=0.178$ ) shows no single dominant factor exists. The three techniques confirm that the common method bias threat is not serious in our case.

Table 2

\section{Reliability and convergent validity}

\begin{tabular}{|c|c|c|c|c|c|}
\hline Variables & Items & $\begin{array}{l}\text { Standardized } \\
\text { factor loadings }\end{array}$ & AVE & Cronbach's $\alpha$ & $\begin{array}{l}\text { Composite } \\
\text { Reliability }\end{array}$ \\
\hline \multirow{5}{*}{$\begin{array}{l}\text { strategic } \\
\text { innovation }\end{array}$} & $\begin{array}{l}\text { Compared to your major competitors, how would you } \\
\text { rate your firm's innovativeness in the following areas: }\end{array}$ & & & & \\
\hline & Our business model is quite unique. & 0.768 & $67.29 \%$ & 0.890 & 0.892 \\
\hline & $\begin{array}{l}\text { Our strategies are different from other firms in our } \\
\text { industry. }\end{array}$ & 0.807 & & & \\
\hline & $\begin{array}{l}\text { Our firm strives to maintain the uniqueness of our } \\
\text { strategies. }\end{array}$ & 0.867 & & & \\
\hline & Our strategies have great potential value. & 0.836 & & & \\
\hline \multirow{5}{*}{$\begin{array}{l}\text { management } \\
\text { innovation }\end{array}$} & $\begin{array}{l}\text { Compared to your major competitors, how would you } \\
\text { rate your firm's innovativeness in the following areas: }\end{array}$ & & & & \\
\hline & $\begin{array}{l}\text { We are more innovative than our competitors in } \\
\text { deciding what methods to use to achieve our targets } \\
\text { and objectives. }\end{array}$ & 0.762 & $57.59 \%$ & 0.838 & 0.844 \\
\hline & $\begin{array}{l}\text { We are more innovative than our competitors in } \\
\text { initiating new procedures or systems. }\end{array}$ & 0.795 & & & \\
\hline & $\begin{array}{l}\text { We are more innovative than our competitors in } \\
\text { developing new ways of achieving our targets and } \\
\text { objectives. }\end{array}$ & 0.808 & & & \\
\hline & $\begin{array}{l}\text { We are more innovative than our competitors in } \\
\text { initiating changes in the job contents and work } \\
\text { methods of our staff. }\end{array}$ & 0.662 & & & \\
\hline \multirow{4}{*}{$\begin{array}{l}\text { technological } \\
\text { innovation }\end{array}$} & $\begin{array}{l}\text { Compared to your major competitors, how would you } \\
\text { rate your firm's innovativeness in the following areas: }\end{array}$ & & & & \\
\hline & $\begin{array}{l}\text { developing new products, processes, and } \\
\text { technologies }\end{array}$ & 0.705 & $62.12 \%$ & 0.831 & 0.830 \\
\hline & $\begin{array}{l}\text { conducting revolutionary scientific research and } \\
\text { technological inventions }\end{array}$ & 0.783 & & & \\
\hline & $\begin{array}{l}\text { developing highly original and innovative products } \\
\text { and services }\end{array}$ & 0.868 & & & \\
\hline \multirow{5}{*}{$\begin{array}{l}\text { firm } \\
\text { competitiveness }\end{array}$} & $\begin{array}{l}\text { Compared to your major competitors, how would you } \\
\text { rate your firm's competitiveness in the following areas: }\end{array}$ & & & & \\
\hline & We often defeat our competitors in the marketplace. & 0.689 & $62.96 \%$ & 0.867 & 0.871 \\
\hline & $\begin{array}{l}\text { Our company can provide higher quality products } \\
\text { and services to customers. }\end{array}$ & 0.729 & & & \\
\hline & $\begin{array}{l}\text { Our company can recognize market changes in } \\
\text { competition rules more promptly. }\end{array}$ & 0.878 & & & \\
\hline & $\begin{array}{l}\text { Our company can respond to new market } \\
\text { opportunities more promptly. }\end{array}$ & 0.861 & & & \\
\hline
\end{tabular}




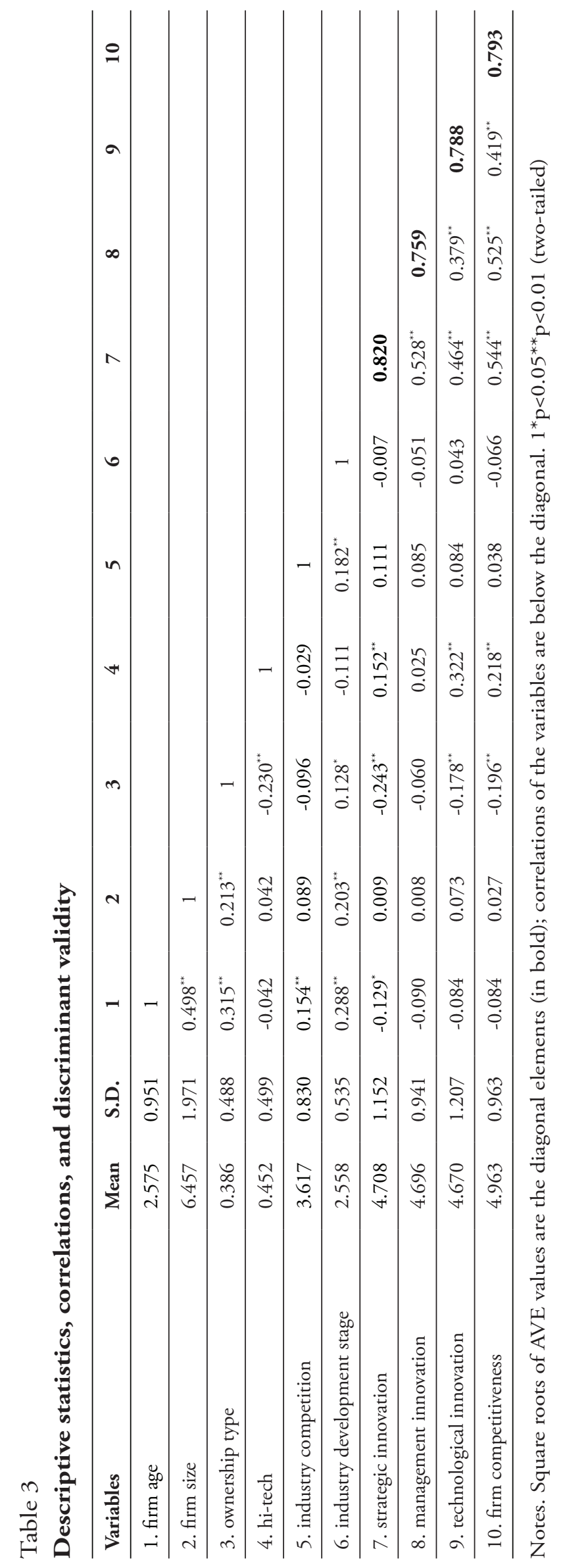




\subsection{Hypotheses testing}

Our model is a typical representation of a multiple mediation model which involves an independent variable (strategic innovation), two serial mediators (management innovation and technological innovation), and a dependent variable (firm competitiveness). Hayes (2013) outlines the procedure for empirical tests using Process Macro, which has become the template for later studies and is generally utilized by scholars when studying this kind of multiple mediation model (Boies, Fiset, \& Gill, 2015; Hayes, 2013; Kashyap \& Rangnekar, 2016; Otterbring, Pareigis, Wästlund, Makrygiannis, \& Lindström, 2018; Owens \& Hekman, 2016;
Russo, Buonocore, Carmeli, \& Guo, 2018; Tan \& Lee, 2017; Tsang, Carpenter, Roberts, Frisch, \& Carlisle, 2014; Valentine, Li, Penke, \& Perrett, 2014). Based on the recommendations of Hayes (2013), Process Macro (version: 2.16.3) for SPSS (version 22.0) was used in our empirical tests. According to the Process model templates (Hayes, 2013), our theoretical model conforms to Model 6. 5,000 to 10,000 bootstrap samples are sufficient in most applications. Thus, 5,000 bootstrap samples with $95 \%$ bias-corrected confidence intervals (CIs) were executed. The standardized regression coefficients for all routes are listed in Figure 2, and the direct, indirect, and total effects are shown in Table 4.

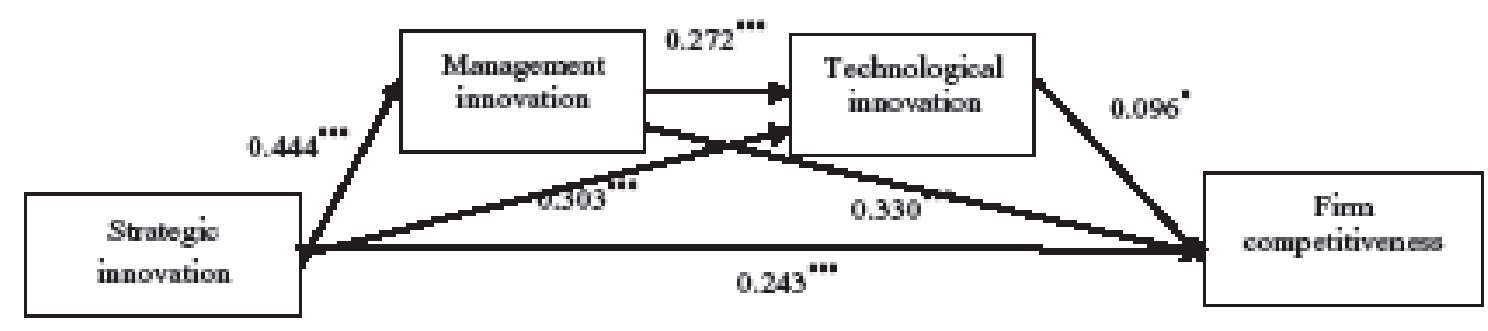

Figure 2. Chain multiple mediation model result.

Notes. ${ }^{*} \mathrm{p}<0.05,{ }^{* *} \mathrm{p}<0.01 ;{ }^{* * *} \mathrm{p}<0.001$ (two-tailed significance); H1: strategic innovation $\rightarrow$ management innovation $\rightarrow$ firm competitiveness; H2: strategic innovation $\rightarrow$ technological innovation $\rightarrow$ firm competitiveness; H3: relative mediation effect: management innovation>technological innovation; H4: strategic innovation $\rightarrow$ management innovation $\rightarrow$ technological innovation $\rightarrow$ firm competitiveness

Table 4

Mediating effects of management innovation, technological innovation, their comparison, and effect size

\begin{tabular}{|c|c|c|c|c|}
\hline & Coefficient & SE & LLCI $(95 \%)$ & ULCI (95\%) \\
\hline Total effect & 0.430 & 0.042 & 0.347 & 0.513 \\
\hline Direct effect & 0.243 & 0.048 & 0.149 & 0.338 \\
\hline \multicolumn{5}{|l|}{ Indirect effects } \\
\hline Total indirect effect & 0.187 & 0.035 & 0.124 & 0.261 \\
\hline Route 1: via management innovation & 0.146 & 0.030 & 0.091 & 0.211 \\
\hline Route 2: via management and technological innovations & 0.012 & 0.008 & 0.001 & 0.032 \\
\hline Route 3: via technological innovation & 0.029 & 0.017 & 0.001 & 0.068 \\
\hline Route 1 minus route 2 & 0.135 & 0.033 & 0.074 & 0.203 \\
\hline Route 1 minus route 3 & 0.117 & 0.036 & 0.054 & 0.195 \\
\hline Route 2 minus route 3 & -0.017 & 0.015 & -0.058 & 0.003 \\
\hline
\end{tabular}




\begin{tabular}{lcccc}
\hline & Coefficient & SE & LLCI (95\%) & ULCI (95\%) \\
\hline Total indirect effect & 0.222 & 0.041 & 0.149 & 0.310 \\
\hline Route 1: via management innovation & 0.174 & 0.034 & 0.112 & 0.246 \\
\hline Route 2: via management and technological innovations & 0.014 & 0.009 & 0.001 & 0.038 \\
\hline Route 3: via technological innovation & 0.034 & 0.021 & 0.001 & 0.082 \\
\hline Percent mediation $\left(\mathrm{P}_{\mathrm{M}}\right)$ & & & & \\
\hline Total indirect effect & 0.434 & 0.093 & 0.276 & 0.635 \\
\hline Route 1: via management innovation & 0.340 & 0.075 & 0.212 & 0.515 \\
\hline Route 2: via management and technological innovations & 0.027 & 0.019 & 0.001 & 0.077 \\
\hline Route 3: via technological innovation & 0.067 & 0.042 & 0.001 & 0.166 \\
\hline
\end{tabular}

Notes. LLCI=Lower Limit of Confidence Interval; ULCI=Upper Limit of Confidence Interval

The serial multiple mediation model as depicted in Figure 1 shows that strategic innovation impacts firm competitiveness through four possible routes: (1) the indirect effect from strategic innovation to firm competitiveness through management innovation only (hypothesis 1); (2) the indirect effect from strategic innovation to firm competitiveness through technological innovation only (hypothesis 2); (3) the indirect effect from strategic innovation to firm competitiveness through both management innovation and technological innovation in serial mediation with management innovation affecting technological innovation (hypothesis 4 ); and (4) the direct effect from strategic innovation to firm competitiveness (if it exists) without passing through either management innovation or technological innovation (We do not hypothesize this in our manuscript since in models with mediation hypotheses it is the indirect effects which are of interest to scholars rather than the direct effect. The only importance of whether the direct effect is significant or not is it differentiates the mediation into full mediation or partial mediation).

According to Hays (2013), bootstrap confidence intervals for indirect effects (specific, total, or pairwise comparisons between) are calculated by repeatedly resampling from the data with replacement, estimating the model in each bootstrap sample, calculating the indirect effects, and deriving the endpoints of a confidence interval for each. An indirect effect (or a difference between two indirect effects) can be deemed different from zero with a\% confidence if zero is outside of $\mathrm{a} \%$ confidence interval. If the confidence interval straddles 0 , this supports the claim that the indirect effect (or the difference between) is not statistically different from zero. In our case, indirect effects are regarded as statistically and significantly different from zero at $95 \%$ CIs or $\mathrm{p}<0.05$ level if $95 \%$ bias-corrected CIs do not straddle zero.

The mediating effect of management innovation (route 1) is 0.146 with $95 \%$ biascorrected CIs [0.091, 0.211] excluding 0 , supporting the positive mediating effect of management innovation in the relationship between strategic innovation and firm competitiveness (hypothesis 1). Similarly, the mediating effect via technological innovation (route 3) is $0.029 .95 \%$ bias-corrected CIs [0.001 , 0.068] excludes 0 , indicating the mediating role of technological innovation is statistically significant at the $\mathrm{p}<0.05$ level, supporting hypothesis 2 .

According to Hays (2013), hypothesis 3 is a typical pairwise comparison of two specific indirect effects (via management innovation vs. via technological innovation). It is common practice for the comparison of the relative magnitude of two specific indirect effects to be achieved by generating a contrast and estimating the endpoints of the CI for this contrast. To test 
hypothesis 3, this study generated a contrast variable (route 1 minus route 3 ) to compare the relative mediation strength of management innovation and technological innovation. If the bias-corrected CIs (for a specific indirect effect or the pairwise comparisons between two indirect effects) do not include 0 (95\% biascorrected CIs in our case), we can be sure to say that this indirect effect or the contrast (pairwise comparison) is statistically significant at $95 \%$ CIs or the $\mathrm{p}<0.05$ level (Hayes, 2013). As shown in Table 4, the indirect effect of this contrast variable (route 1 minus route 3 ) is significantly positive (coefficient $=0.117,95 \%$ bias-corrected CIs [0.054, 0.195], demonstrating that the mediation effect of management innovation is significantly larger than that of technological innovation, lending support to hypothesis 3.

The indirect effect of route 2 is used to test the serial mediation effect of management innovation and technological innovation proposed in hypothesis 4 . Table 4 depicts that the indirect effect for this route, i.e. the link of "strategic innovation $\rightarrow$ management innovation $\rightarrow$ technological innovation $\rightarrow$ firm competitiveness," is 0.012 with $95 \%$ biascorrected CIs ranging from 0.001 to 0.032 . Because zero lies outside of this CI, the serial mediation effect of management innovation and technological innovation is statistically significant. Thus, hypothesis 4 received empirical support. Besides, the direct effect linking strategic innovation to firm competitiveness is 0.243 with 95\% bias-corrected CIs [0.149, 0.338$]$ above 0 , further indicating management innovation and technological innovation partially mediate the relationship linking strategic innovation to firm competitiveness. To ease understanding, we listed in Table 5 the path, the standardized indirect effect, level of significance, and empirical result for each hypothesis.

Table 5

Path, standardized indirect effect, level of significance, and result

\begin{tabular}{|l|l|c|c|c|}
\hline Hypothesis & Path & $\begin{array}{c}\text { Standardized } \\
\text { indirect effect }\end{array}$ & $\begin{array}{c}\text { Significant } \\
\text { or not }^{\mathbf{1}}\end{array}$ & \multicolumn{1}{c|}{ Result } \\
\hline 1 & Strategic inn. $\rightarrow$ management inn. $\rightarrow$ competitiveness & 0.146 & Yes & Supported \\
\hline 2 & Strategic inn. $\rightarrow$ technological inn. $\rightarrow$ competitiveness & 0.029 & Yes & Supported \\
\hline 3 & Mediation effect: management inn. $>$ technological inn. & $0.146>0.029$ & Yes & Supported \\
\hline 4 & $\begin{array}{l}\text { Strategic inn. } \rightarrow \text { management inn. } \rightarrow \text { technological } \\
\text { inn. } \rightarrow \text { competitiveness }\end{array}$ & 0.012 & Yes Supported \\
\hline
\end{tabular}

Notes. 1: at 95\% bias-corrected confidence intervals (5000 bootstrapping samples); inn.=innovation

Our study evaluated the size of mediation effects with completely standardized indirect effect $\left(a b_{c s}\right)$ and percent mediation $\left(P_{M}\right)$ to facilitate our interpretation of the results. The $\mathrm{ab}_{\mathrm{cs}}$ for route 1,2 , and 3 are $0.174,0.014$, and 0.034 respectively, with $95 \%$ bias-corrected CIs all above 0 ([0.112, 0.246], [0.001, 0.038], and $[0.001,0.082]$ respectively). Also, the $\mathrm{P}_{\mathrm{M}}$ values for total indirect effect and route 1,2 , and 3 are $0.434,0.340,0.027$, and 0.067 . This shows that management innovation and technological innovation jointly account for almost half of the total effect, indicating a good mediation effect size.

\section{Discussion and Implication}

This paper starts with the relationship among strategic innovation, management innovation, and technological innovation, and proceeds to construct a research framework discussing how they jointly improve firm competitiveness. Empirical tests from survey data collected from 303 firms in China support the chain multiple mediation effects between 
strategic innovation and firm competitiveness, with management innovation and technological innovation as mediating variables. Specifically, strategic innovation enhances firm competitiveness through management innovation, technological innovation, and the serial chain mediating route of management innovation and technological innovation. Also, management innovation is a more prominent mediator than technological innovation, exerting a more significant mediation effect.

\section{I Theoretical contributions}

This paper contributes to the field of innovation, especially non-technological innovation, in two ways.

First, we introduce a fine-grained typology of non-technological innovations, which includes strategic innovation and management innovation, and link them to technological innovation and firm competitiveness to build an integrated research framework to analyze the interplay between three types of firm innovations and firm competitiveness. By building connections between non-technological innovation, technological innovation, and firm competitiveness, this paper enriches the previously under-researched area of other non-technological innovation besides management innovation, thus expanding the current understanding of the relationship between 1) multiple types of non-technological innovations and 2) non-technological innovation and technological innovation.

In recent years, researchers have been paying more attention to non-technological innovations, and are gradually recognizing the overlooked role of non-technological innovations in promoting technological innovation and firm performance (Azar \& Ciabuschi, 2017; Camisón \& VillarLópez, 2014; Hervas-Oliver, Ripoll-Sempere, \& Moll, 2016; Hervas-Oliver, Sempere-Ripoll, \& Boronat-Moll, 2014; Hervas-Oliver, SempereRipoll, Boronat-Moll, \& Rojas-Alvarado, 2018; Mol \& Birkinshaw, 2012; Nieves, 2016; SempereRipoll, Hervás-Oliver, \& M, 2014; Volberda et al.,
2013; Volberda et al., 2014). However, compared with technological innovation, research in nontechnological innovation is still fragmented and underdeveloped (Camisón \& Villar-López, 2014; Černe et al., 2016; Hervas-Oliver \& SempereRipoll, 2015). Part of the reasons is the time lag of non-technological innovation compared with technological innovation. Academic interest in and research on non-technological innovations started much later, but with more evident exponential growth, whereas technological innovation research began earlier but has grown more steadily (Černe et al., 2016).

Researchers are endeavoring to more deeply explore the area of non-technological innovations. They acknowledge that the lack of a consistent taxonomy and integrated research frameworks are the most important reasons behind the stagnant development and evolution of non-technological innovation, which engenders a lack of connections among the research streams on non-technological innovations. However, management innovation still captures the focus of attention in non-technological innovation, and other types of non-technological innovations such as strategic innovation and marketing innovation are relatively less researched (Meyer-Brötz, Stelzer, Schiebel, \& Brecht, 2018).

Černe and colleagues (2016) clarify the research arena of non-technological innovations and resolve the conceptual ambiguities and fragmentation issues by putting forward the notion that non-technical innovation is an umbrella construct encompassing many other types of innovation such as management, marketing, strategic, business model, and green innovation. More in-depth research in subfields of non-technological innovations such as strategic innovation, marketing innovation, and management innovation is urgently needed (Lopes, Vieira, Barbosa, \& Parente, 2017). Also, building theoretical connections between the seemingly unrelated types of non-technological innovations and technological innovation is also a promising direction (Khosravi, Newton, 
\& Rezvani, 2019; Volberda et al., 2013). This paper responds to these calls by constructing a research model of the joint influence of three types of innovations, i.e., strategic innovation and management innovation as two types of non-technological innovations and technological innovation, on long-term firm competitiveness.

Second, this paper expands the empirical evidence on non-technological innovation by using a Chinese sample. We respond to the call for "a more detailed dataset obtained from a questionnaire specifically designed to understand the relation between non-technological innovations and technological innovations" proposed by Geldes, Felzensztein, and PalaciosFenech (2017). The majority of existing studies on non-technological innovation are empirically set in market economies, with Europe and the US being the most popular ones (Walker et al., 2015). Compared with foreign companies, Chinese enterprises are still technology-based and technology-oriented, and their recognition and implementation of non-technological innovations are incredibly lacking (Guo, Su, \& Ahlstrom, 2016). Against this background, nontechnological innovation in China may generate novel empirical results which will enrich the extant results obtained from the EU and the US. Our findings place strategic innovation in an overarching role to promote management and technological innovation, thus enhancing firm competitiveness. Also, they show that management innovation exerts a bigger mediating effect than technological innovation in the link from strategic innovation to firm competitiveness, thus bringing management innovation into a parallel position with technological innovation and helping to increase the academic interest in and attention paid to management innovation.

\subsection{Managerial implications}

This study also provides some enlightenment on managerial practices. First, our study integrates technological and two crucial types of non-technological innovations, i.e., strategic innovation and management innovation, to analyze their impacts on firm competitiveness. Although strategic innovation, management innovation, and technological innovation are carried out in distinct areas of organizational operations, they collectively contribute to improving firm competitiveness. Innovation is the engine that drives the development of enterprises. Firms should place a strong emphasis on innovation, especially the crucial yet previously overlooked types of non-technological innovations, such as strategic innovation.

Second, the three types of innovations contribute to firm competitiveness in distinctive ways. Strategic innovation not only directly affects firm competitiveness but also indirectly impacts firm competitiveness by promoting technological innovation and management innovation. Therefore, companies should emphasize the overarching position of strategic innovation in fostering firm competitiveness, and at the same time embrace technological and management innovations. Through utilizing the direct and indirect mechanisms linking strategic innovation to firm competitiveness and paying close attention to strategic innovation, firms actively define markets and competition rules, integrate internal resources, improve adaptability and flexibility to respond to changes, and seize opportunities in the external environment to stand out from competitors.

\section{$5 \cdot 3$ Limitations}

Despite its theoretical and practical importance, this study has two disadvantages. First, the cross-sectional data cannot fully illustrate the causality between variables. Subsequent studies can further verify the model using time-series data or panel data to enhance credibility. Second, the institutional environment is an essential driving force of innovation in China's transition economy. Future researchers may consider how institutions moderate the relationship in our model. 


\section{Nota}

1 The province-level GDP ranking in 2009 was compiled by the National Bureau of Statistics of China, which can be found in the China Statistical Yearbook 2010 (http:// www.stats.gov.cn/tjsj/ndsj/2010/indexeh.htm).

\section{References}

Afuah, A. (2009). Strategic innovation: new game strategies for competitive advantage. New York: Taylor \& Francis.

Armbruster, H., Bikfalvi, A., Kinkel, S., \& Lay, G. (2008). Organizational innovation: The challenge of measuring non-technical innovation in large-scale surveys. Technovation, 28(10), 644-657. doi:https://doi.org/10.1016/j. technovation.2008.03.003

Armstrong, J. S., \& Overton, T. S. (1977). Estimating nonresponse bias in mail surveys. Journal of Marketing Research, 1, 396-402.

Azar, G., \& Ciabuschi, F. (2017). Organizational innovation, technological innovation, and export performance: The effects of innovation radicalness and extensiveness. International Business Review, 26(2), 324-336. doi:https://doi.org/10.1016/j. ibusrev.2016.09.002

Bagozzi, R. P., \& Yi, Y. (1988). On the evaluation of structural equation models. Journal of the Academy of Marketing Science, 16(1), 74-94.

Berghman, L., Matthyssens, P., \& Vandenbempt, K. (2012). Value innovation, deliberate learning mechanisms and information from supply chain partners. Industrial Marketing Management, 41(1), 27-39. doi:https://doi.org/10.1016/j. indmarman.2011.11.014

Birkinshaw, J., Hamel, G., \& Mol, J. M. (2008). Management Innovation. Academy of Management Review, 33(4), 825-845. doi:10.5465/amr.2008.34421969

Boies, K., Fiset, J., \& Gill, H. (2015). Communication and trust are key: Unlocking the relationship between leadership and team performance and creativity. The Leadership Quarterly, 26(6), 1080-1094.

Camisón, C., \& Villar-López, A. (2014). Organizational innovation as an enabler of technological innovation capabilities and firm performance. Journal of Business Research, 67(1), 2891-2902. doi:https://doi.org/10.1016/j. jbusres.2012.06.004

Carpenter, M. A., Geletkanycz, M. A., \& Sanders, W. G. (2004). Upper echelons research revisited: Antecedents, elements, and consequences of top management team composition. Journal of Management, 30(6), 749-778. doi:10.1016/j. jm.2004.06.001

Černe, M., Jaklič, M., \& Škerlavaj, M. (2015). Management innovation enters the game: Reconsidering the link between technological innovation and financial performance AU Černe, Matej. Innovation, 17(4), 429-449. doi:1 0.1080/14479338.2015.1126530

Černe, M., Kaše, R., \& Škerlavaj, M. (2016). Nontechnological innovation research: Evaluating the intellectual structure and prospects of an emerging field. Scandinavian Journal of Management, 32(2), 69-85. doi:https://doi.org/10.1016/j. scaman.2016.02.001

Chandler, A. (1962). Strategy and structure. Cambridge: MIT Press.

Chen, Y. (2006). Marketing Innovation. Journal of Economics \& Management Strategy, 15(1), 101123. doi:doi:10.1111/j.1530-9134.2006.00093.x

Crick, D., \& Crick, J. (2016). The first export order: A marketing innovation revisited AU Crick, Dave. Journal of Strategic Marketing, 24(2), 77-89. doi:10.1080/0965254X.2014.1001870

Crossan, M. M., \& Apaydin, M. (2010). A multi-dimensional framework of organizational innovation: A systematic review of the literature. 
Journal of Management Studies, 47(6), 1154-1191. doi:10.1111/j.1467-6486.2009.00880.x

Daft, R. L. (1978). A dual-core model of organizational innovation. The Academy of Management Journal, 21(2), 193-210. doi: $10.2307 / 255754$

Damanpour, F., \& Aravind, D. (2012). Managerial innovation: Conceptions, processes, and antecedents. Management and Organization Review, 8(2), 423-454. doi:10.1111/j.17408784.2011.00233.x

Damanpour, F., \& Evan, W. M. (1984). Organizational innovation and performance: The problem of "organizational lag". Administrative Science Quarterly, 29(3), 392-409. doi: $10.2307 / 2393031$

Damanpour, F., Sanchez-Henriquez, F., \& Chiu, H. H. (2018). Internal and external sources and the adoption of innovations in organizations. British Journal of Management, 29(4), 712-730. doi:10.1111/1467-8551.12296

Damanpour, F., Szabat, K. A., \& Evan, W. M. (1989). The relationship between types of innovation and organizational performance. Journal of Management Studies, 26(6), 587-602. doi:10.1111/j.1467-6486.1989.tb00746.x

Doha, A., Pagell, M., Swink, M., \& Johnston, D. (2017). Measuring firms' imitation activity. R\&D Management, 47(4), 522-533. doi:10.1111/ radm. 12217

Douglas, S. P., \& Craig, C. S. (2006). On improving the conceptual foundations of international marketing research. Journal of International Marketing, 14(1), 1-22. doi:10.1509/jimk.14.1.1

Engert, S., Rauter, R., \& Baumgartner, R. J. (2016). Exploring the integration of corporate sustainability into strategic management: A literature review. Journal of Cleaner Production, 112, 2833-2850. doi:https://doi.org/10.1016/j. jclepro.2015.08.031
Fisher, R. J. (1993). Social desirability bias and the validity of indirect questioning. Journal of Consumer Research, 20(2), 303-315.

Fornell, C., \& Larcker, D. F. (1981). Evaluating structural equation models with unobservable variables and measurement error. Journal of Marketing Research, 18(1), 39-50. doi:10.2307/3151312

Foss, N. J., \& Saebi, T. (2017). Fifteen years of research on business model innovation: How far have we come, and where should we go? Journal of Management, 43(1), 200-227. doi:10.1177/0149206316675927

Foss, N. J., \& Saebi, T. (2018). Business models and business model innovation: Between wicked and paradigmatic problems. Long Range Planning, 51(1), 9-21. doi:https://doi.org/10.1016/j. lrp.2017.07.006

Gebauer, H., Worch, H., \& Truffer, B. (2012). Absorptive capacity, learning processes and combinative capabilities as determinants of strategic innovation. European Management Journal, 3O(1), 57-73. doi:https://doi. org/10.1016/j.emj.2011.10.004

Geldes, C., Felzensztein, C., \& Palacios-Fenech, J. (2017). Technological and non-technological innovations, performance and propensity to innovate across industries: The case of an emerging economy. Industrial Marketing Management, 61, 55-66. doi:https://doi.org/10.1016/j. indmarman.2016.10.010

Geroski, P. (1998). Thinking creatively about your market: Crisps, perfume and business strategy. Business Strategy Review, 9(2), 1-10. doi:10.1111/1467-8616.00060

Ghisetti, C., Marzucchi, A., \& Montresor, S. (2015). The open eco-innovation mode: An empirical investigation of eleven European countries. Research Policy, 44(5), 1080-1093. doi:https://doi.org/10.1016/j.respol.2014.12.001 
Goldman, S. L., Nagel, R. N., \& Preiss, K. (1995). Agile competitors and virtual organizations: Strategies for enriching the customer. New York: Van Nostrand Reinhold.

Gopalakrishnan, S., \& Damanpour, F. (1997). A review of innovation research in economics, sociology and technology management. Omega, 25(1), 15-28. doi:https://doi.org/10.1016/ S0305-0483(96)00043-6

Gunday, G., Ulusoy, G., Kilic, K., \& Alpkan, L. (2011). Effects of innovation types on firm performance. International Journal of Production Economics, 133(2), 662-676. doi:https://doi. org/10.1016/j.ijpe.2011.05.014

Guo, H., Su, Z., \& Ahlstrom, D. (2016). Business model innovation: The effects of exploratory orientation, opportunity recognition, and entrepreneurial bricolage in an emerging economy. Asia Pacific Journal of Management, 33(2), 533-549.

Guo, H., Tang, J., Su, Z., \& Katz, J. A. (2017). Opportunity recognition and SME performance: The mediating effect of business model innovation. R\&D Management, 47(3), 431-442. doi:doi:10.1111/radm.12219

Hamel, G. (1996). Strategy as revolution. Harvard Business Review, 74(4), 69-71.

Hamel, G. (1998a). The challenge today: Changing the rules of the game. Business Strategy Review, 9(2), 19-26. doi:10.1111/14678616.00062

Hamel, G. (1998b). Strategy emergence. Executive Excellence, 15(12), 3-4.

Hamel, G. (1998c). Strategy innovation and the quest for value. Sloan Management Review, 39(2), 7-14.

Hamel, G. (1999). New wealth. Executive Excellence, 16(4), 3-4.
Hamel, G., \& Prahalad, C. K. (1989). Strategic intent. Harvard Business Review, 67(3), 63-76.

Hamel, G., \& Prahalad, C. K. (1993). Strategy as stretch and leverage. Harvard Business Review, 71(2), 75-84.

Hamel, G., \& Prahalad, C. K. (1994a). Competing for the future. Harvard Business Review, 72(4), 122-128.

Hamel, G., \& Prahalad, C. K. (1994b). Corporate imagination and expeditionary marketing. Harvard Business Review, 69(4), 81-93.

Han, J. K., Kim, N., \& Srivastava, R. K. (1998). Market orientation and organizational performance: Is innovation a missing link? Journal ofMarketing, 62(4), 30-45. doi:10.2307/1252285

Hargrave, T. J., \& Van De Ven, A. H. (2006). A Collective Action Model of Institutional Innovation. The Academy of Management Review, 31(4), 864-888. doi:10.2307/20159256

Hart, S. L. (1992). An Integrative Framework for Strategy-Making Processes. The Academy of Management Review, 17(2), 327-351. doi: $10.2307 / 258775$

Hayes, A. F. (2013). Introduction to mediation, moderation, and conditional process analysis: $A$ regression-based approach. New York, NY, US: Guilford Press.

Hervas-Oliver, J. L., Ripoll-Sempere, F., \& Moll, C. B. (2016). Does management innovation pay-off in SMEs? Empirical evidence for Spanish SMEs. Small Business Economics, 47(2), 507-533.

Hervas-Oliver, J. L., \& Sempere-Ripoll, F. (2015). Disentangling the influence of technological process and product innovations. Journal of Business Research, 68(1), 109-118. doi:https://doi. org/10.1016/j.jbusres.2014.04.010

Hervas-Oliver, J. L., Sempere-Ripoll, F., \& Boronat-Moll, C. (2014). Process innovation 
strategy in SMEs, organizational innovation and performance: a misleading debate? Small Business Economics, 43(4), 873-886.

Hervas-Oliver, J. L., Sempere-Ripoll, F., BoronatMoll, C., \& Rojas-Alvarado, R. (2018). On the joint effect of technological and management innovations on performance: Increasing or diminishing returns? Technology Analysis \& Strategic Management, 30(5), 569-581.

Hitt, M. A., Ireland, R. D., \& Hoskisson, R. E. (2012). Strategic management cases: Competitiveness and globalization: Cengage Learning.

Hollen, R. M. A., Van Den Bosch, F. A. J., \& Volberda, H. W. (2013). The role of management innovation in enabling technological process innovation: An inter-organizational perspective. European Management Review, 10(1), 35-50. doi:10.1111/emre.12003

Kashyap, V., \& Rangnekar, S. (2016). Servant leadership, employer brand perception, trust in leaders and turnover intentions: A sequential mediation model. Review of Managerial Science, 10(3), 437-461.

Khosravi, P., Newton, C., \& Rezvani, A. (2019). Management innovation: A systematic review and meta-analysis of past decades of research. European Management Journal. doi:https://doi. org/10.1016/j.emj.2019.03.003

Kim, C. W., \& Mauborgne, R. (1997). Value innovation: The strategic logic of high growth. Harvard Business Review, 75(1), 102-112.

Kim, C. W., \& Mauborgne, R. (1999a). Creating new market space. Harvard Business Review, 77(1), 83-93.

Kim, C. W., \& Mauborgne, R. (1999b). Strategy, value innovation, and the knowledge economy. Sloan Management Review, 40(3), 41-45.

Klewitz, J., \& Hansen, E. G. (2014). Sustainability-oriented innovation of SMEs: A systematic review. Journal of Cleaner Production, 65, 57-75. doi:https://doi.org/10.1016/j. jclepro.2013.07.017

Kline, R. B. (2010). Principles and practice of structural equation modeling (3rd ed). New York: Guilfor Press.

Kodama, M. (2004). Business innovation through strategic community creation: A case study of multimedia business field in Japan. Journal of Engineering and Technology Management, 21(3), 215-235. doi:https://doi.org/10.1016/j. jengtecman.2003.05.002

Kriauciunas, A., Parmigiani, A., \& Rivera-Santos, M. (2011). Leaving our comfort zone: Integrating established practices with unique adaptations to conduct survey-based strategy research in nontraditional contexts. Strategic Management Journal, 32(9), 994-1010. doi:10.1002/smj.921

Krinsky, R., \& Jenkins, A. C. (1997). Collide: When the uneasy fusion of strategy and innovation. Strategy \& Leadership, 25(4), 37-41. doi:10.1108/ eb054594

Lam, A. (2005). Organizational innovation. Oxford: Oxford University Press.

Le Bas, C., Mothe, C., \& Nguyen-Thi, T. U. (2015). The differentiated impacts of organizational innovation practices on technological innovation persistence. European Journal of Innovation Management, 18(1), 110-127.

Lee, S. M., Olson, D. L., \& Trimi, S. (2010). Strategic innovation in the convergence era. International Journal of Management and Enterprise Development, 9(1), 1-12.

Li, H., \& Atuahene-Gima, K. (2001). Product innovation strategy and the performance of new technology ventures in China. The Academy of Management Journal, 44(6), 1123-1134. doi:10.2307/3069392 
Lopes, D. P. T., Vieira, N. d. S., Barbosa, A. C. Q., \& Parente, C. (2017). Management innovation and social innovation: Convergences and divergences. Academia Revista Latinoamericana de Administración, 30(4), 474-489. doi:doi:10.1108/ ARLA-05-2016-0150

Luk, C.-L., Yau, O. H. M., Sin, L. Y. M., Tse, A. C. B., Chow, R. P. M., \& Lee, J. S. Y. (2008). The effects of social capital and organizational innovativeness in different institutional contexts. Journal of International Business Studies, 39(4), 589-612.

Lynn, G. S., Morone, J. G., \& Paulson, A. S. (1996). Marketing and discontinuous innovation: The probe and learn process. California Management Review, 38(3), 8-37. doi:10.2307/41165841

Markides, C. (1997). Strategic innovations. Sloan Management Review, 38(3), 9-23.

Markides, C. (1998). Strategic innovation in established companies. Sloan Management Review, 39(3), 31.

Markides, C. (1999). A dynamic view of strategy. Sloan Management Review, 40(3), 55-63.

Meyer-Brötz, F., Stelzer, B., Schiebel, E., \& Brecht, L. (2018). Mapping the technology and innovation management literature using hybrid bibliometric networks. International Journal of Technology Management, 77(4), 235-286.

Milutinović, R., Stošić, B., \& Mihić, M. (2015). Concepts and importance of strategic innovation in SMEs: Evidence from Serbia. Management:Journal of Sustainable Business and Management Solutions in Emerging Economies(77), $35-42 \% \mathrm{~V} 20$.

Minagawa Jr., T., Trott, P., \& Hoecht, A. (2007). Counterfeit, imitation, reverse engineering and learning: reflections from Chinese manufacturing firms. R\&D Management, 37(5), 455-467. doi:doi:10.1111/j.1467-9310.2007.00488.x
Mol, M. J., \& Birkinshaw, J. (2012). Relating management innovation to product and process innovation: Private rents versus public gains. Cheltenham: Edwar Elgar.

Neugebauer, F., Figge, F., \& Hahn, T. (2016). Planned or emergent strategy making? Exploring the formation of corporate sustainability strategies. Business Strategy and the Environment, 25(5), 323336. doi:10.1002/bse. 1875

Nieves, J. (2016). Outcomes of management innovation: An empirical analysis in the services industry. European Management Review, 13(2), 125-136.

Nieves, J., \& Diaz-Meneses, G. (2016). Antecedents and outcomes of marketing innovation: An empirical analysis in the hotel industry. International Journal of Contemporary Hospitality Management, 28(8), 1554-1576. doi:10.1108/IJCHM-11-2014-0589

Nunnally, J. (1978). Psychometric methods. New York: McGraw.

Otterbring, T., Pareigis, J., Wästlund, E., Makrygiannis, A., \& Lindström, A. (2018). The relationship between office type and job satisfaction: Testing a multiple mediation model through ease of interaction and well-being. Scandinavian journal of work, environment \& health, 44(3), 330-334.

Owens, B. P., \& Hekman, D. R. (2016). How does leader humility influence team performance? Exploring the mechanisms of contagion and collective promotion focus. Academy of Management Journal, 59(3), 10881111.

Podsakoff, P. M., MacKenzie, S. B., Lee, J. Y., \& Podsakoff, N. P. (2003). Common method biases in behavioral research: A critical review of the literature and recommended remedies. $J$ Appl Psychol, 88(5), 879-903. doi:10.1037/00219010.88.5.879 
Podsakoff, P. M., \& Organ, D. W. (1986). SelfReports in organizational research: Problems and prospects. Journal of Management, 12(4), 531544. doi:10.1177/014920638601200408

Priem, R. L., Butler, J. E., \& Li, S. (2013). Toward reimagining strategy research: Retrospection and prospection on the 2011 AMR decade award article. Academy of Management Review, 38(4), 471-489. doi:10.5465/amr.2013.0097

Raes, A. M. L., Heijltjes, M. G., Glunk, U., \& Roe, R. A. (2011). The interface of the top management team and middle managers: A process model. Academy of Management Review, 36(1), 102-126. doi:10.5465/amr.2009.0088

Rapert, M. I., Velliquette, A., \& Garretson, J. A. (2002). The strategic implementation process: Evoking strategic consensus through communication. Journal of Business Research, 55(4), 301-310. doi:https://doi.org/10.1016/ S0148-2963(00)00157-0

Russo, M., Buonocore, F., Carmeli, A., \& Guo, L. (2018). When family supportive supervisors meet employees' need for caring: Implications for work-family enrichment and thriving. Journal of Management, 44(4), 1678-1702.

Sabherwal, R., \& Becerra-Fernandez, I. (2005). Integrating specific knowledge: Insights from the Kennedy Space Center. IEEE Transactions on Engineering Management, 52(3), 301-315. doi:10.1109/TEM.2005.851269

Schiederig, T., Tietze, F., \& Herstatt, C. (2012). Green innovation in technology and innovation management: An exploratory literature review. R\&D Management, 42(2), 180-192. doi:doi:10.1111/j.1467-9310.2011.00672.x

Schlegelmilch, B. B., Diamantopoulos, A., \& Kreuz, P. (2003). Strategic innovation: The construct, its drivers and its strategic outcomes. Journal of Strategic Marketing, 11(2), 117-132.
Schumpeter, J. A. (1934). The theory of economic development. Cambridge: Harvard University Press.

Sempere-Ripoll F., Hervás-Oliver JL., \& M, P.-O. (2014). Combining technological and management innovations: Empirical evidence of a premium effect:: Springer.

Simmonds, K., \& Smith, H. (1968). The first export order: A marketing innovation. European Journal of Marketing, 2(2), 93-100. doi:10.1108/ EUM0000000005244

Stata, R. (1989). Organizational learning-the key to management innovation. MIT Sloan Management Review, 30(3), 63-74.

Tan, C.-S., \& Lee, Q.-W. (2017). The role of self-esteem and social support in the relationship between extraversion and happiness: A serial mediation model. Current Psychology, 36(3), 556-564.

Teece, D. J. (2010). Business models, business strategy and innovation. Long Range Planning, 43(2), 172-194. doi:https://doi.org/10.1016/j. lrp.2009.07.003

Tether, B. S., \& Tajar, A. (2008). The organisational-cooperation mode of innovation and its prominence amongst European service firms. Research Policy, 37(4), 720-739. doi:https:// doi.org/10.1016/j.respol.2008.01.005

Tsang, J.-A., Carpenter, T. P., Roberts, J. A., Frisch, M. B., \& Carlisle, R. D. (2014). Why are materialists less happy? The role of gratitude and need satisfaction in the relationship between materialism and life satisfaction. Personality and Individual Differences, 64, 62-66.

Vaccaro, I. G., Jansen, J. J. P., Van Den Bosch, F. A. J., \& Volberda, H. W. (2012). Management innovation and leadership: The moderating role of organizational size. Journal of Management Studies, 49(1), 28-51. doi:10.1111/j.14676486.2010.00976.x 
Valentine, K. A., Li, N. P., Penke, L., \& Perrett, D. I. (2014). Judging a man by the width of his face: The role of facial ratios and dominance in mate choice at speed-dating events. Psychological science, 25(3), 806-811.

Volberda, H. W., Van Den Bosch, F. A. J., \& Heij, C. V. (2013). Management innovation: Management as fertile ground for innovation. European Management Review, 10(1), 1-15. doi:10.1111/emre.12007

Volberda, H. W., Van Den Bosch, F. A. J., \& Mihalache, O. R. (2014). Advancing management innovation: Synthesizing processes, levels of analysis, and change agents. Organization Studies, 35(9), 1245-1264. doi:10.1177/0170840614546155

Walker, R. M., Chen, J., \& Aravind, D. (2015). Management innovation and firm performance: An integration of research findings. European Management Journal, 33(5), 407-422. doi:https:// doi.org/10.1016/j.emj.2015.07.001

Wischnevsky, D. J., \& Damanpour, F. (2008). Radical strategic and structural change: Occurrence, antecedents and consequences.
International Journal of Technology Management, 44(1), 53-80.

Womack, J. P., Jones, D. T., \& Roos, D. (2007). The machine that changed the world: The story of lean production, Toyota's secret weapon in the global car wars that is revolutionizing world industry. New York: Free Press.

Wu, L.-Y., Wang, C.-J., Chen, C.-P., \& Pan, L.-Y. (2008). Internal resources, external network, and competitiveness during the growth stage: A Study of taiwanese high-tech ventures1. Entrepreneurship Theory and Practice, 32(3), 529-549. doi:10.1111/ j.1540-6520.2008.00239.x

Yiu, D. W., \& Lau, C.-M. (2008). Corporate entrepreneurship as resource capital configuration in emerging market firms. Entrepreneurship Theory and Practice, 32(1), 37-57. doi:10.1111/j.15406520.2007.00215.x

Zott, C., \& Amit, R. (2008). The fit between product market strategy and business model: Implications for firm performance. Strategic Management Journal, 29(1), 1-26. doi:10.1002/ smj.642 


\section{Supporting Agencies:}

The Ministry of Education Humanities and Social Science Project (No. 19YJAZH019); The Program for National Natural Science Foundation of China (No. 71502083)

\section{Authors:}

1. Chen Han, Bachelor's degree in English and Finance and PhD candidate in Management, Xi'an Jiaotong University, Xi’an, P.R. China.E-mail: hanchen0219@stu.xjtu.edu.cn

ORCID

(iD) 0000-0001-9224-1335

2. Shanxing Gao, PhD in Management, Xi'an Jiaotong University, Xi'an, P.R. China. Email: gaozn@mail.xjtu.edu.cn

ORCID

(iD) 0000-0002-6648-2933

\section{Contribution of each author:}

\begin{tabular}{lcc}
\hline Contribution & Chen Han & Shanxing Gao \\
\hline 1. Definition of research problem & $\sqrt{ }$ \\
2. Development of hypotheses or research questions (empirical studies) & $\sqrt{ }$ \\
3. Development of theoretical propositions (theoretical work) & $\sqrt{ }$ \\
4. Theoretical foundation/ Literature review & $\sqrt{ }$ \\
5. Definition of methodological procedures & $\sqrt{ }$ \\
6. Data collection & $\sqrt{ }$ \\
7. Statistical analysis & $\sqrt{ }$ \\
8. Analysis and interpretation of data & $\sqrt{ }$ \\
9. Critical revision of the manuscript & $\sqrt{ }$ \\
10. Manuscript writing & $\sqrt{ }$ \\
11. Other (supervision) & $\sqrt{ }$ \\
\hline
\end{tabular}

\section{Erratum}

Where was written:

“Review of Business Management, São Paulo, v.21, n.5, p.879-905, oct/dec. 2019.”

Now read:

“Rev. Bras. Gest. Neg. São Paulo v.21 n.4 oct-dec. 2019 p. 879-905” 